units and referring doctors. Any such studies of developmental outcomes will be carried out by the in vitro fertilisation units or groups working with them. The register would facilitate rapid assessment of numbers and where the families were living. Viable national or regional registers would be a prerequisite for international collaborative studies of pregnancies achieved by in vitro fertilisation.

We thank members of the in vitro fertilisation units for providing data to the register, and staff of the National Perinatal Statistics Unit for data processing and other work. The National Perinatal Statistics Unit is funded by a grant from the Commonwealth Department of Health.

\section{References}

1 Wood C, Trounson A, Leeton JF, et al. Clinical features of eight pregnancies resulting from in vitro fertilization and embryo transfer. Fertil Steril 1982;38: 22-9.
2 Edwards RG, Steptoe PC. Current status of in-vitro fertilisation and implantation of human embryos. Lancet 1983;ii:1265-9.

Lopata A. Concets in human in vitro fertilization and embryo transfer. Fertil Steril 1983;40:289-301.

Jansen RPS. Spontaneous abortion incidence in the treatment of infertility. $\mathrm{Am} \mathfrak{3}$ Obstet Gynecol 1982;143:451-73

Australian Bureau of Statistics. Perinatal deaths, Australia, 1982. Canberra: Commonwealth Government Printer, 1984

6 Yovich JL, Stanger JD, Grauaug A, et al. Monozygotic twins from in vitro fertilization. Fertil Steril 1984;41:833-7.

ealth Commission of Victoria. Survey of perinatal deaths in Victoria. Melbourne:

8 Steptoe PC. Discussion on the laparoscopic recovery of oocytes. In: Edwards RG, Purdy JM, eds. Human conception in vitro. London: Academic Press, 1982: 119-32.

Kerin JF, Warnes GM, Quinn PJ, et al. Incidence of multiple pregnancy after in-vitro fertilisation and embryo transfer. Lancet 1983;ii:537-40.

10 Craft I, Porter R, Green S, et al. Success of fertility, embryo number, and invitro fertilisation. Lancet $1984 ; \mathrm{i}: 732$.

11 Speirs AL, Trounson A, Warnes GM, Yovich JL, Saunders DM, Chen C. Summary of results. In: Wood C, Trounson A, eds. Clinical in vitro fertilization.

12 Warkany J. Congenital malformations. Chicago: Year Book Medical Publishers,

13 Wood C. The Tracy Maund obstetrical lecture. The beginning of life. Med f Aust $1981 ; \mathrm{i}: 305-12$.

14 Yovich J, Puzey A, De'Atta R, Roberts R, Reid S, Grauaug A. In-vitro fertilisation pregnancy with early progestagen support. Lancet 1982 ;ii:378-9.

(Accepted 1 August 1985)

\begin{abstract}
Decisions about coronary care made by 39 randomly selected general practitioners in New Zealand over one year were investigated. Demographic variables and variables relating to the patient's condition, history, and social circumstances were assessed for 113 patients, and practitioners' belief about the relevance of each variable to the decision was elicited. A comparison was made between the objective criteria found to be related to the decision, the criteria believed by the practitioners to be relevant to the decision, and a theoretical model of what should govern the decision to admit. The theoretical model was found to be built into the beliefs of the practitioners, but the objective model was far simpler.

Further research is needed to determine whether the use of the more complex, theoretical models will confer any benefit, in terms of patient wellbeing, over the pragmatic model in use at present.
\end{abstract}

\section{Introduction}

In recent years there has been considerable discussion about decision making by doctors. ${ }^{1-5}$ Most of this discussion, however,

Christchurch Clinical School, Christchurch, New Zealand

A E STEPHENSON, MB, DIPOBST, department of community health

D M FERGUSSON, BA, department of paediatrics

A R HORNBLOW, PHD, associate professor, department of community health

$D W$ BEAVEN, FRCP, FRACP, department of medicine

$S$ J CHETWYND, PHD, department of community health

Correspondence and requests for reprints to: Associate Professor A R Hornblow, Department of Community Health, PO Box 4345, Christchurch, New Zealand. has focused on the theoretical criteria that ought to govern decision making rather than on how doctors actually arrive at decisions. In general, three decision models can be identified that may be applied to any clinical decision. The first is the theoretical and prescriptive model proposed by accepted medical opinion; the second is based on the beliefs of individual general practitioners about the criteria that are relevant to their decision making; and the third is the decision model that may be derived from statistical analysis of the factors associated with various decisions. Clearly, considerable discrepancies may occur between these three decision models as the beliefs of individual general practitioners may not exactly reflect current medical opinion and the actual decisions made may differ from the beliefs held by the individual general practitioner or those expressed by accepted authorities.

We report a study of decisions on coronary care made by a sample of general practitioners in New Zealand. We set out to examine three questions. Firstly, what factors discriminate patients suspected of having acute myocardial infarction who are admitted to hospital from those who are treated at home? Secondly, what factors do general practitioners believe are relevant in the decision to admit patients with acute myocardial infarction to hospital or to treat them at home? Thirdly, how well do the objective factors that actually discriminate between those patients treated in hospital and those treated at home compare with the beliefs of general practitioners and the accepted medical opinion about the criteria that should be used in making the decision to admit the patient to hospital ?

\section{Method}

SAMPLE

We studied 113 consecutive patients presenting with suspected acute myocardial infarction. These patients represented all such 
cases seen by 39 randomly selected general practitioners resident in the Christchurch urban area. For 30 of the general practitioners the period of study was one year and for the remaining nine it was six months.

\section{MEASUREMENTS}

For each case of suspected acute myocardial infarction we collected the following information.

Firstly, whether or not the patient had been admitted to hospital as a result of the initial consultation.

Secondly, each patient's history was obtained using a standard questionnaire answered by the general practitioner. The information collected comprised 12 variables. (1) When the patient was seen missing information, however, indicated that it was not significantly associated with the decision to admit. This suggested that the few missing data did not bias the results.

\section{Results}

FACTORS ASSOCIATED WITH THE DECISION TO ADMIT

Table I shows the relations between whether the patient was admitted to hospital and the series of 12 measures of the circumstances surrounding the consultation, the age of the patient, the clinical severity of the acute myocardial infarction, the patient and family history of cardiac disease, and the patient's social background. Each comparison was tested for significance with the $\chi^{2}$ test or Fisher's exact test.

TABLE I-Effect of variables on decisions about coronary care

\begin{tabular}{|c|c|c|c|c|c|}
\hline Variable & & No & $\begin{array}{l}\text { No (proportion) admitted } \\
\text { to hospital }\end{array}$ & $x^{2}$ & p Value \\
\hline $\begin{array}{l}\text { When seen } \\
\text { During working hours } \\
\text { Outside working hours }\end{array}$ & $\begin{array}{l}77 \\
36\end{array}$ & 113 & $\begin{array}{l}49(0.64) \\
31(0.86)\end{array}$ & $5 \cdot 00$ & 0.01 \\
\hline $\begin{array}{l}\text { Where seen } \\
\text { Other than at home } \\
\text { At home }\end{array}$ & $\begin{array}{l}40 \\
73\end{array}$ & 113 & $\begin{array}{l}20(0.50) \\
60(0.82)\end{array}$ & 12.95 & 0.0003 \\
\hline $\begin{array}{l}\text { Knowledge of patient } \\
\text { Known to general practitioner } \\
\text { Not known to general practitioner }\end{array}$ & $\begin{array}{l}76 \\
37\end{array}$ & 113 & $\begin{array}{l}55(0.72) \\
25(0.68)\end{array}$ & $0 \cdot 28$ & 0.60 \\
\hline $\begin{array}{l}\text { Patient age } \\
\text { Over } 70 \\
\text { Under } 70\end{array}$ & 28 & 113 & $\begin{array}{l}18(0.64) \\
62(0.73)\end{array}$ & 0.76 & 0.38 \\
\hline $\begin{array}{l}\text { No of clinical signs and symptoms } \\
0-1 \\
2 \\
3 \\
4-7\end{array}$ & $\begin{array}{l}24 \\
38 \\
21 \\
23\end{array}$ & 106 & $\begin{array}{l}9(0.38) \\
30(0.79) \\
16(0.76) \\
22(0.96)\end{array}$ & 21.93 & 0.0001 \\
\hline $\begin{array}{l}\text { Cardiac history } \\
\text { Absent } \\
\text { Present }\end{array}$ & $\begin{array}{l}33 \\
78\end{array}$ & 111 & $\begin{array}{l}20(0.61) \\
59(0.76)\end{array}$ & 2.55 & 0.11 \\
\hline $\begin{array}{l}\text { Family cardiac history } \\
\text { Absent } \\
\text { Present }\end{array}$ & $\begin{array}{l}83 \\
18\end{array}$ & 101 & $\begin{array}{l}58(0.70) \\
13(0.72)\end{array}$ & 0.04 & 0.84 \\
\hline $\begin{array}{l}\text { Other serious illness } \\
\text { Absent } \\
\text { Present }\end{array}$ & $\begin{array}{l}79 \\
33\end{array}$ & 112 & $\begin{array}{l}55(0.70) \\
24(0.73)\end{array}$ & 0.11 & 0.74 \\
\hline $\begin{array}{l}\text { Home circumstances } \\
\text { Support } \\
\text { No support }\end{array}$ & $\begin{array}{l}99 \\
12\end{array}$ & 111 & $\begin{array}{r}70(0.71) \\
9(0.75)\end{array}$ & $0 \cdot 10$ & 0.76 \\
\hline $\begin{array}{l}\text { Family responsibilities } \\
\text { No dependents } \\
\text { Dependents }\end{array}$ & 27 & 111 & $\begin{array}{l}19(0.70) \\
60(0.71)\end{array}$ & 0.01 & 0.92 \\
\hline $\begin{array}{l}\text { Work responsibilities } \\
\text { Absent } \\
\text { Present }\end{array}$ & $\begin{array}{l}75 \\
38\end{array}$ & 113 & $\begin{array}{l}50(0.67) \\
30(0.79)\end{array}$ & $1 \cdot 83$ & $0 \cdot 18$ \\
\hline $\begin{array}{l}\text { Financial state* } \\
\text { Average or above } \\
\text { Below average }\end{array}$ & $\begin{array}{r}106 \\
5\end{array}$ & 111 & $\begin{array}{r}76(0.72) \\
3(0.60)\end{array}$ & & 0.57 \\
\hline
\end{tabular}

*Fisher's exact test.

(during or outside working hours). (2) Where the patient was seen (at his home or elsewhere). (3) Whether or not the patient was known to the general practitioner. (4) The patient's age (over or under 70 years). (5) The clinical signs and symptoms. The presence or absence of eight signs and symptoms was noted-namely, abnormal blood pressure, collapse, impaired consciousness, heart failure, abnormal pulse, nausea or vomiting, symptoms of less than 12 hours' duration, and symptoms still present at the time of consultation. These were combined into a single measure of the severity of the acute myocardial infarction by counting the number of these items present at initial consultation. This count ranged from a theoretical value of 0 for patients with no signs or symptoms to a maximum of 8 for patients with all the signs and symptoms. (6) The patient's history of cardiac illness (presence or absence of previous cardiac illness). (7) The family cardiac history (presence or absence of cardiac illness among the patient's first order relatives). (8) Whether or not the patient had any other serious illness. (9) Whether or not the patient had home support. (10) Whether or not the patient had any family responsibilities.

(11) Whether or not the patient was in paid employment. (12) The patient's financial state. This was based on the general practitioner's perception of the general economic condition of the patient and was graded subjectively as "average or above" or "below average."

Thirdly, as the data were being collected general practitioners were asked to rate each of the measures described above as "favours hospital admission," "neutral," or "favours home care."

Information for some variables was missing for some of the patients.

Variations in sample size are indicated in the tables. Analysis of the
Only three measures were related to the decision to admit. (1) Where the patient was seen, admission being more likely if the patient was seen at home rather than elsewhere. Eighty per cent of patients seen elsewhere were seen at the general practitioner's surgery. (2) When the patient was seen, admission being more likely if the patient was seen outside normal working hours-that is, outside $0700-1700$. (3) The number of signs and symptoms, the probability of admission tending to increase with an increasing number of signs and symptoms. Thus patients with fewer than two signs and symptoms had a probability of admission of 0.38 compared with those presenting with four or more signs and symptoms, who had a probability of 0.96 .

The objective model of decision making that emerged from this analysis thus showed only these three criteria as determining the probability of admission. This was confirmed by fitting a logistic regression model to the data.

\section{BELIEFS OF GENERAL PRACTITIONERS ABOUT FACTORS RELEVANT TO} THE DECISION TO ADMIT

Table II shows the relations between the beliefs of general practitioners about the indications or contraindications for admission to hospital in terms of the 12 measures described above and thus provides a measure of the consensus of beliefs among general practitioners about the criteria that are relevant to the decision to admit. Each comparison was tested for significance with the $\chi^{2}$ test, but as multiple significance tests were used, which were sometimes based on small 
numbers, the $\chi^{2}$ statistic is presented as only a rough guide to the degree of consensus about the relevance of each criterion.

The table shows that the general practitioners were significantly in agreement that 11 factors were indications for admission to hospital. These factors were: patient seen out of working hours; patient not known by the general practitioner; age under 70; several signs and symptoms of acute myocardial infarction; history of cardiac illness; family history of cardiac illness; other serious illness; little or no home support; family responsibilities; paid employment; and a below average financial state. The only factor that was not agreed on as being relevant to the decision was where the patient was seen.
RELATIONS BETWEEN PRESCRIPTIVE ACCOUNTS OF DECISION TO ADMIT, BELIEFS OF THE GENERAL PRACTITIONERS, AND OBJECTIVE FACTORS ASSOCIATED WITH ADMISSION

The discrepancy between the objective factors that were related to the decision to admit and beliefs of the general practitioners about the criteria for admission invited comparison with the prescriptive model reported in two influential papers about the criteria that should govern admission to hospital in cases of acute myocardial infarction. ${ }^{6}$ ? Table III gives a qualitative comparison of the factors that were objectively related to the decision, believed by the general practitioners

TABLE II-Opinion of general practitioner about how each variable favoured admission to hospital

\begin{tabular}{|c|c|c|c|c|c|c|c|}
\hline \multirow[b]{2}{*}{ Variable } & \multirow{2}{*}{\multicolumn{2}{|c|}{ No }} & \multicolumn{3}{|c|}{ Opinion of general practitioner } & \multirow[b]{2}{*}{$x^{2}$} & \multirow[b]{2}{*}{ p Value } \\
\hline & & & $\begin{array}{c}\text { Favours } \\
\text { admission }\end{array}$ & Neutral & $\begin{array}{l}\text { Does not favour } \\
\text { admission }\end{array}$ & & \\
\hline $\begin{array}{l}\text { When seen } \\
\text { During working hours } \\
\text { Outside working hours }\end{array}$ & $\begin{array}{l}77 \\
36\end{array}$ & 113 & $\begin{array}{r}5 \\
18\end{array}$ & $\begin{array}{l}59 \\
17\end{array}$ & $\begin{array}{r}13 \\
1\end{array}$ & $29 \cdot 90$ & 0.0001 \\
\hline Where seen & & 113 & & & & $1 \cdot 81$ & $0 \cdot 40$ \\
\hline $\begin{array}{l}\text { Other than at home } \\
\text { At home }\end{array}$ & $\begin{array}{l}40 \\
73\end{array}$ & & $\begin{array}{l}3 \\
9\end{array}$ & $\begin{array}{l}28 \\
54\end{array}$ & $\begin{array}{r}9 \\
10\end{array}$ & & \\
\hline Knowledge of patient & & 113 & & & & $7 \cdot 22$ & 0.03 \\
\hline $\begin{array}{l}\text { Known to general practitioner } \\
\text { Not known to general practitioner }\end{array}$ & $\begin{array}{l}76 \\
37\end{array}$ & & $\begin{array}{l}29 \\
13\end{array}$ & $\begin{array}{l}32 \\
23\end{array}$ & $\begin{array}{r}15 \\
1\end{array}$ & & \\
\hline Patient age & & 113 & & & & $30 \cdot 48$ & 0.0001 \\
\hline $\begin{array}{l}\text { Over } 70 \\
\text { Under } 70\end{array}$ & $\begin{array}{l}28 \\
85\end{array}$ & & $\begin{array}{r}1 \\
45\end{array}$ & $\begin{array}{l}10 \\
28\end{array}$ & $\begin{array}{l}17 \\
12\end{array}$ & & \\
\hline No of clinical signs and symptoms & & 106 & & & & 39.84 & 0.0001 \\
\hline 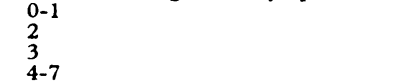 & $\begin{array}{l}24 \\
38 \\
21 \\
23\end{array}$ & & $\begin{array}{r}1 \\
13 \\
10 \\
20\end{array}$ & $\begin{array}{r}8 \\
18 \\
5 \\
2\end{array}$ & $\begin{array}{r}15 \\
7 \\
6 \\
1\end{array}$ & & \\
\hline Cardiac history & & 111 & & & & $18 \cdot 77$ & 0.0001 \\
\hline $\begin{array}{l}\text { Absent } \\
\text { Present }\end{array}$ & $\begin{array}{l}33 \\
78\end{array}$ & & $\begin{array}{r}4 \\
43\end{array}$ & $\begin{array}{l}21 \\
29\end{array}$ & $\begin{array}{l}8 \\
6\end{array}$ & & \\
\hline Family cardiac history & & 101 & & & & $56 \cdot 66$ & 0.0001 \\
\hline $\begin{array}{l}\text { Absent } \\
\text { Present }\end{array}$ & $\begin{array}{l}83 \\
18\end{array}$ & & $\begin{array}{r}1 \\
12\end{array}$ & $\begin{array}{r}78 \\
6\end{array}$ & 4 & & \\
\hline Other serious illness & & 112 & & & & $9 \cdot 63$ & 0.008 \\
\hline $\begin{array}{l}\text { Absent } \\
\text { Present }\end{array}$ & $\begin{array}{l}79 \\
33\end{array}$ & & $\begin{array}{l}11 \\
13\end{array}$ & $\begin{array}{l}51 \\
13\end{array}$ & $\begin{array}{r}17 \\
7\end{array}$ & & \\
\hline Home circumstances & & 111 & & & & $7 \cdot 82$ & 0.02 \\
\hline $\begin{array}{l}\text { Support } \\
\text { No support }\end{array}$ & $\begin{array}{l}99 \\
12\end{array}$ & & $\begin{array}{r}21 \\
7\end{array}$ & $\begin{array}{r}47 \\
3\end{array}$ & $\begin{array}{r}31 \\
2\end{array}$ & 100 & 80 \\
\hline Family responsibilities & & 111 & & & & $4 \cdot 47$ & $0 \cdot 11$ \\
\hline $\begin{array}{l}\text { No dependents } \\
\text { Dependents }\end{array}$ & $\begin{array}{l}27 \\
84\end{array}$ & & 8 & $\begin{array}{l}24 \\
59\end{array}$ & $\begin{array}{r}3 \\
17\end{array}$ & & \\
\hline Work responsibilities & & 113 & & & & 12.54 & 0.002 \\
\hline $\begin{array}{l}\text { Absent } \\
\text { Present }\end{array}$ & $\begin{array}{l}75 \\
38\end{array}$ & & 6 & $\begin{array}{l}67 \\
29\end{array}$ & $\begin{array}{l}8 \\
3\end{array}$ & & \\
\hline Financial state & & 111 & & & & $6 \cdot 23$ & 0.04 \\
\hline $\begin{array}{l}\text { Average or above } \\
\text { Below average }\end{array}$ & $\begin{array}{r}106 \\
5\end{array}$ & & $\begin{array}{l}2 \\
1\end{array}$ & $\begin{array}{r}96 \\
4\end{array}$ & 8 & & \\
\hline
\end{tabular}

TABLE III-Comparison of three decision models in terms of variables indicating admission to hospital

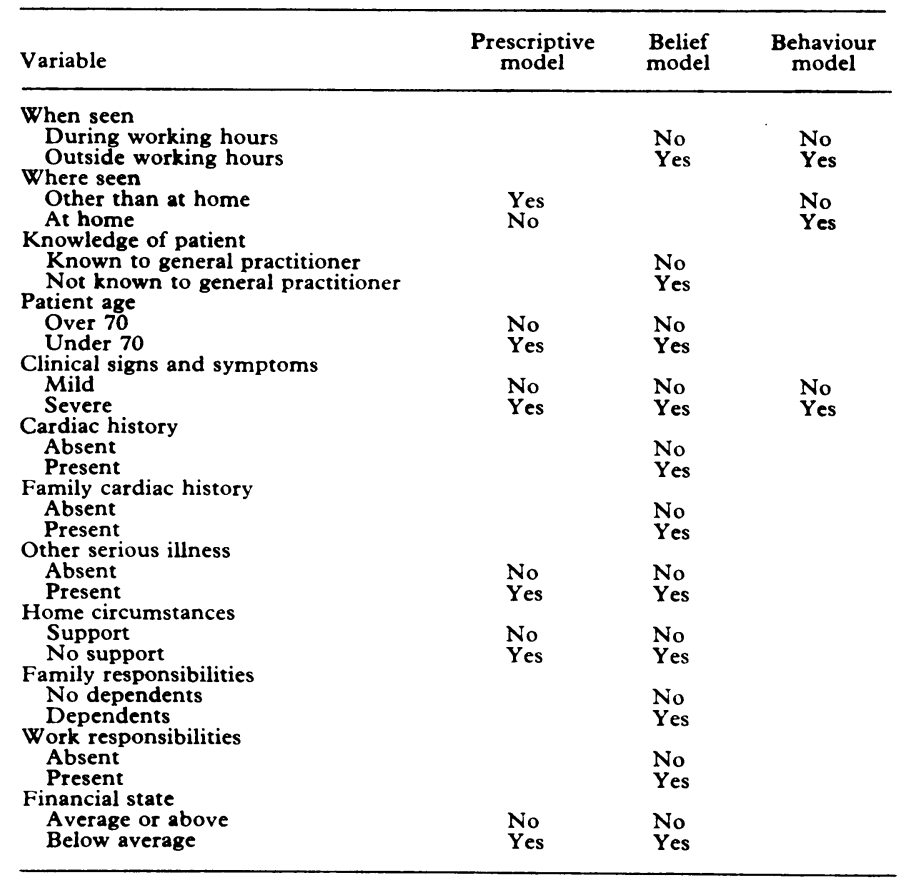

to be relevant to the decision, and deemed to be relevant to the decision by currently accepted medical opinion. These comparisons show that there was less than perfect agreement between current medical opinion, the beliefs of the general practitioners, and the criteria that were actually related to admission. Specifically, the objective analysis suggested the presence of a simple three factor model in which the severity of acute myocardial infarction and the time and place of consultation were the sole determinants of admission to hospital. On the other hand, both accepted medical opinion and the beliefs of general practitioners presented a more elaborate model in which several criteria were deemed to be important in the decision to admit. Comparisons of accepted medical opinion and the beliefs of general practitioners showed that there was substantial agreement between the two but that the beliefs of general practitioners tended to be more elaborate and were also based on some criteria deemed irrelevant by accepted medical opinion.

Collectively, the results in table III suggested that an "official" theory of decision making exists that is based on several criteria and is well reflected, albeit in an overelaborate form, in the beliefs of general practitioners. In practice, however, the decision to admit a patient to hospital or treat a patient at home was based on a limited model in which how ill the patients seemed and the circumstances under which they were seen were the major determinants of the decision.

\section{Discussion}

Our analysis provides a case study of the discrepancies that may arise between medical theory and clinical practice. Though 
both the beliefs of the general practitioners and accepted medical opinion indicated that the decision to admit a patient with acute myocardial infarction to hospital should be based on multiple clinical and social criteria, in practice the statistical analysis suggested that the decision to admit was often based on simple and immediate criteria: those patients who had severe symptoms of acute myocardial infarction, who were seen at home, or who were seen outside surgery hours were more likely to be admitted to hospital.

This pronounced discrepancy between medical theory and practice raises several issues. Perhaps the most important of these is the extent to which this discrepancy holds for other processes of medical decision making. Generally, the results hint that there may be two distinct models of medical decision making. The first is that reflected in the professional and scientific reports, whereas the second is that reflected in the actual decision making of doctors. Our results raise the possibility that what doctors and medical reports recommend should be done is quite different from what is done in practice. In view of the small number of subjects studied and the fact that we limited our research to a single decision, however, it would be unwise to generalise the results too widely. Nevertheless, the pronounced discrepancy we found between accepted theory and actual practice is thought provoking.

Our research was limited to a management decision, and we did not consider the more complex issue of whether variations in management decisions affect the outcome of acute myocardial infarction. Clearly, further research is required to examine the relations between medical theory, the clinical decisions of medi- $\varrho$ cal practitioners, and the outcomes of these decisions to determine whether any discrepancies between theory and practice have a bearing on the outcomes of the decision.

We thank the general practitioners who took part in the study. क The study was supported by grants from the Medical Research Coun- 0 cil of New Zealand and the Canterbury Medical Research Foundation.

\section{References}

1 Lusted LB. Introduction to medical decision making. Springfield: Charles C Thomas, 1968.

2 Albert DA. Decision theory in medicine: a review and critique. Milbank Mem

Elstein AS, Shulman LS, Sprafka SA. Medical problem solving: an analysis of clinstein MC, Fineberg HV. Clinical decision analysis. Philadelphia: W Saunders, 1980

Pauker SG. Prescr

(o medical decision making. American Behavioural Scientist 1982;25:507-22.

6 Council of the Royal College of General Practitioners. Guidelines for admittin patients with myocardial infarction to hospital. $\mathcal{F} R$ Coll Gen Pract 1974;2A 824-31.

7 Joint Working Party of the Royal College of Physicians of London and the British Cardiac Society. $\mathcal{Z} R$ Coll Physicians Lond 1975;10:5-46.

(Accepted 29 fuly 1985)

\title{
Vitamin D deficiency in adult British Hindu Asians: a family disorder
}

\author{
SUNIL SHAUNAK, KAY COLSTON, LISA ANG, SWATEE P PATEL，J D MAXWELL
}

\begin{abstract}
The vitamin $D$ state of 60 apparently healthy adult Hindu Asian couples living in Britain was studied on a community basis. Twenty six (22\%) of the Asian subjects had pronounced vitamin $D$ deficiency, defined as 25hydroxycholecalciferol concentrations below $10 \mathrm{nmol} / 1$ (4 $\mathrm{ng} / \mathrm{ml}$ ), while none of the white controls had such low concentrations. Asian men and women were equally affected, and plasma concentrations were similar in husbands and wives. Vitamin supplements were being taken by only $31(26 \%)$ subjects, most of whom were women.
\end{abstract}

It is suggested that the spouses of patients with osteomalacia should be screened for vitamin D deficiency.

\section{Introduction}

Over the past 20 years attention has been drawn to the high prevalence of rickets and osteomalacia in British Asians. ${ }^{1-3}$ This problem was first recognised in the Pakistani Moslem community in Glasgow and subsequently emerged among east

St George's Hospital and Medical School, London SW17 ORE

SUNIL SHAUNAK, MB, MRCP, house officer in medicine

KAY COLSTON, BSC, PHD, lecturer in chemical pathology

LISA ANG, MSC, research assistant

SWATEE P PATEL, MSC, research statistician, department of epidemiology J D MAXWELL, MD, FRCP, senior lecturer in medicine

Correspondence to: Dr J D Maxwell, Department of Medicine II, St George's Hospital Medical School, London SW17 ORE.
African Asians living in London despite their normal 25hydroxycholecalciferol (25-OHD) concentrations on arrival in the United Kingdom. ${ }^{4}$ A later study of British Asians by different subgroups suggested that deficiency was most severe in Hindus. ${ }^{5}$

We became interested in the vitamin $D$ state of spouses after several women with proved osteomalacia said that their partners had similar symptoms. Among the five couples initially studied three spouses also had low 25-OHD concentrations. None had consulted a doctor. As both dietary and social factors might influence the development of nutritional osteomalacia in Asians we studied the relation between 25-OHD concentrations in married couples in a community based survey.

\section{Methods}

We obtained all samples over six weeks in late spring. At social meetings of local Punjabi and Gujarati associations 60 healthy couples volunteered (about $80 \%$ of all couples present), ranging in age from 21 to 75 . Two interviewers who spoke Hindi used a preset questionnaire to collect demographic information, obtain details of symptoms, and take a simple dietary history. Subjects receiving treatment that might interfere with vitamin D metabolism were excluded. Forty eight healthy white volunteers (laboratory, nursing, medical, and paramedical staff) aged 18-62 served as controls.

Plasma was immediately separated and stored (at $-20^{\circ} \mathrm{C}$ ) for subsequent biochemical analysis of 25-OHD concentrations by competitive protein binding assay. ${ }^{6}$ Plasma calcium and phosphate concentrations and alkaline phosphatase activity were measured using standard automated techniques. The association between each variable and 25-OHD concentration was examined using the $\chi^{2}$ test or $t$ test, as appropriate. Multiple regression analysis was used to examine further the contribution of vitamin supplements and margarine to plasma 25-OHD concentrations. .

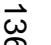
. 